\title{
Women as Human Rights Defenders at Risk - A Present Case Example
}

\author{
Siroos Mirzaei ${ }^{1}$, Jan Kizilhan ${ }^{2}$, Reem Alksiri ${ }^{3}$ and Thomas Wenzel ${ }^{4 *}$ \\ ${ }^{1}$ Hemayat Treatment Centre, Vienna, Austria \\ ${ }^{2}$ Duale Universität Baden-Würtemberg, Deutschland and University of Dohuk, Iraq \\ ${ }^{3}$ World Psychiatric Association Scientific Section on Psychological Aspects of persecution and Torture, and International Organisation of Persecuted \\ Women (Syrian Women's International Initiative), Austria \\ ${ }^{4}$ World Psychiatric Association Scientific Section on Psychological Aspects of Persecution and Torture, and Section on Psychiatry, Medicine and Prima- \\ ry Care, Austria
}

${ }^{\star}$ Corresponding author: Thomas Wenzel, WPA Scientific Section on Primary Health Care, Austria

Received: January 01, 2022; Accepted: January 07, 2022; Published: January 14, 2022

\begin{abstract}
November 29 has been appointed as International Women Human Rights Defenders Day, while persecution, imprisonment, cruel and unusual punishment, torture, and even extra-legal killings, are unfortunately frequent in many countries. The UN declaration against torture, or the Bangkok rules for the treatment of women as prisoners are often ignored in this context. In our short report we want to draw attention to a recent important case in Iran, that demonstrates the violation of human rights and potential health impact in a country singled out by the UN and many international NGOs for such violations. Both domestic and political violence must be addressed by strong efforts by the international community and national bodies, not only because of the adverse individual and public health impact, but also to protect the concept of human rights as a preventive factor in itself. Independent monitoring of the safety and health of women as prisoners, especially in the context of persecution, must be permitted to support this effort.
\end{abstract}

Keywords: Woman, Prison conditions, Torture, Persecution, Iran

Women are globally especially active as human rights defenders, but also at increased risk of persecution, imprisonment, cruel and unusual punishment and torture, as underlined by the installation of the $29^{\text {th }}$ of November as International Women Human Rights Defenders Day, and demonstrated by the recent case of Narges Mohammadi, spokesperson for Iran's Centre for Human Rights Defenders. Women, like the first women surgeon, Homa Shaibany [1], sometimes play an important role as professionals in the history and development of the country, in spite of the barriers facing them in public and professional life, as reported for example by the international NGO Human Rights Watch . Reports by victims and witnesses brought out of the country circumventing the else strict censorship, are frequently the only information on ongoing cases of violations and can at least be used to argue for independent investigation, as for example by the UN special rapporteurs on torture or on Iran.

Well known for both her publications and her firm stance in the defense of human rights in Iran, Mohammadi is back in prison after 13 months of freedom. She had been released on 8 October 2020 after more than five years behind bars and most recently Ms. Mohammadi was arbitrarily arrested and detained again after taking part in a memorial service, as reported by Amnesty International, the OMCT, and other independent international NGOs [2].

Between prison terms, persecution continued. According to personal communication to the author, during her 13 months of freedom, Mohammadi continued to be subjected to judicial harassment, which included being arrested at least eight times, as must be assumed, because of her support for the families of imprisoned journalists and other prisoners of conscience [3]. She was violently attacked by security forces on the street at least three times when she attempted to visit the families of political prisoners or executed prisoners Navid Afkari and Sattar Beheshti, again based on personal communication received by the first author (SM).

Judicial authorities had further confirmed a decision to give her a new sentence of 36 months in prison, 80 lashes and a fine on charges of "anti-government propaganda by means of the publication of false information" and "insulting government officials" [4].

She said on a phone call to her husband, the transcript being shared with the author and again regarding flogging sentence during an online meeting with author, before her arrest (SM): "I'm in security section 2A of Evin prison [a section controlled by the Revolutionary Guards] and they've told me I must serve 30 months in prison and receive 80 lashes, but as long as I live, I won't let myself be flogged." Flogging [2] must be seen as both a form of torture and "cruel and unusual punishment" denounced internationally $[3,4]$.

During imprisonment, she had been exposed to solitary confinement, which is, according to $\mathrm{UN}$, a form of psychological torture, with potentially severe health consequences, also practiced for 
example in the US [5], but forbidden as torture by international human rights standards, as stated by UN Special rapporteur Juan Mendez, and criticized by international expert boards [6-9]. Narges Mohammadi has published two books, which are currently being translated into English and German, and made a documentary film about the consequences of so-called "white torture," in which prisoners are systematically held in solitary confinement for an unknown period of time without even access to a lawyer, under harsh conditions such as being exposed to light or noise all the time, etc. [6]. Conditions described would not violate the prohibitions described in the UN Anti-torture convention [4], but would also violate the special considerations applying to women prisoners as outlined in the UN standards ("Bangkok rules") [10]. Mohammadi had also reportedly been earlier been subjected to direct physical violence by the director of Tehran's Evin prison and several guards when she protested against her transfer to Zanjan prison, $300 \mathrm{~km}$ northwest of Tehran, in December 2019 [8].

The Third Committee of the UN General Assembly, which specialises in human rights issues, meanwhile adopted a resolution on 17 November, condemning Iran yet again for its flagrant human rights abuses, including its crackdowns on protests "using weapons of war," according to Javaid Rehman, the UN special rapporteur on the human rights situation in Iran [9].

It might be noted, that publishing independent scientific research and reporting on human rights violations from countries such as Iran are nearly impossible, and data must frequently make use of reports by victims, family members and international NGOs [11]. The Islamic Republic of Iran is ranked 174th out of 180 countries in RSF's 2021 World Press Freedom Index [10].

The Un Special Rapporteurs should therefore been invited to independently assess the situation of Narges Mohammadi and other, especially women prisoners in Iran. Women as human rights defenders should receive special support and consideration by the international community [12], to be given not only at November 29.

\section{References}

1. Fahimi M, Homa Shaibany (1952) First woman surgeon of Iran. J Am Med Womens Assoc 7: 272-273.

2. Leth PM, Banner J (2005) Forensic medical examination of refugees who claim to have been tortured. Am J Forensic Med Pathol 26: 125-130. [crossref]

3. Lines $\mathrm{R}$ (2008) The right to health of prisoners in international human rights law. Int J Prison Health 4: 3-53. [crossref]

4. Rasmussen OV (2006) The medical aspects of the UN Convention against Torture. Torture 16: 58-64. [crossref]

5. Gawande A (2009) Hellhole: the United States holds tens of thousands of inmates in long-term solitary confinement. Is this torture? New Yorker 36-45. [crossref]

6. Alempijevic D, Beriashvili R, Beynon J, Alempijevic Petersen D, Birmanns B, et al., (2020) Statement of the Independent Forensic Expert Group on Conversion Therapy. Torture 30: 66-78. [crossref]

7. Hunt SC, Orsborn M, Checkoway H, Biggs ML, McFall M, et al., (2008) Later life disability status following incarceration as a prisoner of war. Mil Med 173: 613-618. [crossref]

8. The Istanbul Statement on the Use and Effects of Solitary Confinement. Torture, 2008. 18: 63-66.

9. Smith PS (2008) Solitary confinement. An introduction to the Istanbul Statement on the Use and Effects of Solitary Confinement. Torture 18: 56-62. [crossref]
10. Van Hout MC, S Fleissner, H Stover (2021) \#Me Too: Global Progress in Tackling Continued Custodial Violence against Women: The 10-Year Anniversary of the Bangkok Rules. Trauma Violence Abuse 15248380211036067.

11. Siroos Mirzaei HA, Seyed Zarei, Reem Alksiri (2021) Psychosocial consequences of widespread of torture and sociopolitical pressure in Iran. Social Medicine 14

12. Wenzel T, Alksiri R, den Otter J, Mirzaei S (2020) Special challenges related to persecution and imprisonment for Woman in Syria-aspects of neglected problems in the support of survivors. ARCH Women Health Care 3: 1-3.

\section{Citation:}

Mirzaei S, Kizilhan J, Alksiri R, Wenzel T (2022) Women as Human Rights Defenders at Risk - A Present Case Example. ARCH Women Health Care Volume 5(1): 1-2. 